In a large proportion of the essays $I$ have written, the same subject of plane position has had to be con-idered and described I am, therefore, som?what seriously interested in "pposing as well the disuse of the word "position," which no one can misunderstand, as the nse of the words "aspect," "slope," "tilt," \&c, in a sense not at present assigned (nor properly assignable) to them.

$$
\text { RICHD. A. PROCTOR }
$$

\section{Sea-water Aquaria}

I HAVE read with much gusto your article tpon the Crystal Palace Aquarium. I am induced by it to put forward a caution with regard to the construction of rock-work in tanks.

Several weeks ago. casually looking over a heap of Bangor slaty rock, on the road bordering the Brighton Aquarium works, and being used for the rock-work of tanks, my atteniion was attracted by some bright green patches upon some of the srones, which appeared to me to be carbonate of copper, but was probably silicate. Looking further at one with a lens, I imagined that I could also distinguish particles of peacock ore. On attempting to purloin a specimen, I was very properly stopped from so crinina! an act by the Cerberts in charge. I wrote to the chairman of the company, stating that, not having examined the stone, I might be only contributing a mare's nest to their znological collection, but that if it contained much copper the fish would be in danger. I understand that upon receipt of myletter some rock was sent up to Dr. Percy, whose report, I am told, was to the effect that there was much sulphide of copper, and that the pretty green rock was therefore unfit for tank rock-work.

I think this will serve as a caution to the constructors of aquaria to examine all material which is to be in contact with water most carefully before using it. There are so many minerals which would be delererious that I strongly advise an analysis and report in the case of every untried rock. The accident of my passing a heap of stones has saved the company, with which I am not in the least connected except as a fervent well-wisher, from a large expenditure and a serious scrape.

Allow me to ask those who are accustomed to the management of tanks, whether hydraulic pressure upon a small and strong one would be likely to assist in maintaining life in any of the deep-sea organisms, and whether it would be useful to make recesses for those loving darkness, with the axes opposite the plate glass side, so that a bull's-eye lantern could occasionally throw light upon their actions and mode of life?

Brighton, Oct. 2 I

Marshall hall

\section{ON HOMOPLASTIC AGREEMENTS IN}

\section{PLANTS}

$\Delta T$ the recent meeting of the British Association I pointed out in a short communication the difference that existed between mimicry in animals and what has been spoken of under that name amongst plants. The distinction was sufficiently obvious, and must have occurred to everyone who had given the matter any consideration, but my object was to try to raise a discussion upon the whole subject as exhibited in plants.

I fancy it is hardly sufficiently understood how commonly this agreement of facies occur in plants widely differing in other respects. I will give a few illustrations of it. Humboldt remarks ("Views of Nature," p. 35I) : "In all European colonies the inhabitants have been led by resemblances of physiognomy (habitus, fucies) to apply the names of European forms to certain tropical plants, which bear wholly different flowers and fruits from the genera to which these designations originally referred. Everywhere in both hemispheres the northern settler has believed he could recognise alders, poplars, apple, and olive trees, being misled for the most part by the form of the leaves and the direction of the branches." Nor has the popular eye alone been deceived by these resemblances. Schleiden states ("The Plant,"p. 255) that Australia has in common with Europe a very common plant, the daisy, yet Dr. Hooker has pointed out (Flora of Tasmania, pl. 47) that the plant intended by Schleiden is the very similar but distinct Brachycoma decipiens Hook. fil. Again, true flowering plants bilonging to the very curious family Podostemacece have been figured as liverworts and other cryptogamic plants (Berkeley, Intr. to Crypt. Bot., p. 5). Many other instances of similar errors might be given."

Since I read my paper, I have met with an essay by Schouw, in which he enumerates facts of the same kind. "There is still," he says ("Earth, Plants, and Man,"p. 6r), "another kind of repetition which I might call habitual repetition, or denominate mimicry, if this expression was not at variance with the subjection to law which exists throughout nature, but to comprehend which our powers are oiten insufficient." After various illustrations he proceeds:- "In the genus Mutisia we have the remarkable sight of a compositous flower, with the tendrils of a leguminous plant." (This by an accidental coincidence was one of the instances which I, myself, used at Edin. burgh.) "In Begonia fuchsioides the leaves are similar to a Fuchsia, and very different from the other forms of lear among the begonias, and the colour of the blossom likewise reminds us of the fuchsias. We have another most striking example in certain Brazilian plants, which although possessed of perfectly developed flowers and fruits, mimic, as it were, in their leaves and stems, groups of plants of much lower rank." ( $\mathrm{He}$ is alluding to the Podostemacere mentioned above.) "Lacis fucoides resembles certain seaweeds so much, that it might be mistaken for one by a person who did not see the flowers. Mniopsis scaturiginum strikingly resembles a fungermannia."

I suggested that when a plant put on the characteristic facies of a distinct natural family, it might conveniently be spoken of as a pseudomorph, having in view an obvious analogy in the case of minerals. I do not, however, now think on further consideration, that this term, although convenient, includes all the cases. In small natural families it is not always easy to recognise any general habit or facies at alf, and in the case of plants belonging to different families where this is the case, but having a similar habit, it would be purely arbitrary to fix the pseudomorphism on any of them. Again all the indi. viduals of distinct groups of plants might have a similar habit, and the same remark would apply. The difficulty is, however, got over by speaking of the plants in these cases as isomornhic.

My friend, Mr. E. R. Lankester, has pointed out to me that agreements of this kind may all come under what he has termed homoplasy (Ann. and Mag. of Natural History, July 1870). This is the explanation he gives of this expression :-

"When identical or nearly similar forces, or environments, act on two or more parts of an organism which are exactly or nearly alike, the resulting modifications of the various parts will be exactly or nearly alike. Further, if, instead of similar parts in the same organism, we suppose the same forces to act on parts in two organisms, which parts are exactly or nearly alike and sometimes homogenetic, the resulting correspondences called forth in the several paris in the two organisms will be nearly or exactly alike. I propose to call this kind of agreement homo plasis or homoplasy. The fore legs have a homoplastic agreement with the hind legs, the four extremities being, in their simplest form (e.g. Proteus, which must have had ancestors with quite rudimentary hind legs), very closely similar in structure and function. ... Homoplasy includes all cases of close resemblance of form not traceable to homogeny."

The resemblances, therefore, above described between the vegetative organ of plants with no close generic relations, may be described as homoplastic. The diffictilty

* Perhaps one of the most striking is the Natal cycad Stangerin paradoxa having been published and described by Kunze as a species of Lomarin, a genus of Ferns. 
still, of course, remains to show how the homoplasy has been brought about. In some cases, as in the homoplastic forms of American Cactace and South African Euphorbias, or in the stipular bud scales of many wholly unrelated deciduous trees, the nature of the similar external conditions may possibly be made out with some correctuess. Again, Dr. Seemann has pointed out that by the rivers in Nicaragua and in Viti, the vegetation, although composed of very different plants, puts on the willow form ("Dottings by the Roadside," p. 46). A phenomenon true of two distant places accidentally contrasted, might be expected to obtain more generally; at any rate, among our indigenous riparian plants Lythrum Saicaria and the willow-herb are, as their names indicate, additional illustrations. The band of vegetation that fringes a stream is always densely crowded with individual plants, and it is easy to see that elongated and vertically disposed leaves would be most advantageous, exactly as they are to the gregarious plants of meadows and plains. The homoplastic agreement of riparian plants may be therefore a direct result of selective effort due to the position in which they grow.

In other cases the operation of similar external moulding influences is not so easy to trace. It might, perhaps, lowever, be imagined that plants would hereditarily re. tain the effects when the influences bad ceased to operate, and no new ones had come into operation precisely adapted to obliterate the work of those that preceded them. Suppose, for example, that willows got their habit and foliage from ancestors that were exclusively riparian, then any descendant that happened to be able to tolerate situations with less abundant supplies of moisture, would not necessarily lose their characteristic foliage on that account. Such races finight be expected to occur near rivers subject to periodic droughts, since under these conditions any others would be likely to perish. Under such circumstances we should have cause and effect no longer in contiguity; the riparian habit surviving the riparian situation.

I suggested at Edinburgh that possibly similar habits in plants might be bronght about by different causes. This was only a suggestion, and probably what has just been said is a truer account of the matter. At any rate the illustration I gave of my meaning has been quite misunderstood (as, for example, in the last number of the Popular Science Review). It is well known that there are a certain number of plants indigenous to the British Isles, which are found at a considerable height upon mountains and also upon the sea-shore, but not in the intervining space. In the latter situations they contain more sodium salts than in the former, and inasmuch as these salts are destructive to many plants, those that compose a strand flora must be able to tolerate them, and this of course is an advantage, because many of their competitors are poisoned off. Similarly plants of mountains must have a similar advantage over others in ability to tolerate mountain asperiries of climate. Now, suppose a mountain submerged; its fora and certain portions of that of the strand come to coincide. Then if we suppose the mountain gradually to emerge, some of these plants will spread downwards under the uncovered surface, and travel over the whole of the interval that ultimately scparates the mountain-top and the strand. Why, then, do they not remain there? Simply, I believe, because they are elbowed out by other plants which, nevertheless, cannot tolerate the conditions of life either on the mountain or the shore, and leave these, therefore, as refuges which they are unable to invade. It is possible that the action of similar soil constituents might help to bring about homoplastic agreements in plants. The suggestion is not, however, one that occurred to me to make. My object was simply to show how two perfectly different causes might produce the same effect, namely, that of giving immunity from competition to a small group of plants. Except as an illustration of this point, the matter was quite irrelevant to the subject about which I was speaking. W. T. Thiseliton Dyer

ON THE DISCOVERY OF STEPHANURUS IV THE UNITED STATES AND IN AUSTRALIA

THE time has now arrived when a full statement of the facts relating to this interesting parasite. Stephamurus dcntatus, should be made more generally known; for not only is the progress of helminthological science likely to be checked by delay in this matter, but, in the absence of definite information, the several merits of the original discoverer and describer of this entozoon are likely to be altogether ignored. I therefore reco: d the facts and inferences in the order in which they have recently come under my notice.

On the roth of January last, through the firm of Messrs. Groombridge. I received an undated communication from Prof. W. B. Fletcher, of Indianapolis, Indiana, U.S.A. In that letter Dr. Fletcher announces that he has "found a worm " infesting the hog, and he helps one to realise its abundance by adding that he obtained it "in nine out of ten hogs" which he examined. After recording some other important facts respecting the tissues and organs which were most infested by the parasite, Dr. Fletcher remarks that he cannot find any descripion of the worm in the work on Entozoa issued by the publishers above mentioned, nor in the writings of Von Siebold and Küchenmeister, and he therefore encloses specimens for my determination, requesting a reply.

As I have already stated in my first letter recorded in the British Medical Fournal (for January 14, p. 50, where many other particulars are given which I need not here recapitulate) I was instantly struck with the "strongyloid character " of the fragmentary and shrivelled up specimens, and I nay a!so add that it at once occurred to me that I had had some previous acquaintance with a scientific description of the worm. Proceeding, therefore, to turn over a series of helminthological memoirs, for many of which 1 stand indebted to the late veteran, Dr. K. M. Diesing, of Vienna, I soon had the good fortune to find the desired record. The memoir in question forms part of the "Annalen des Wiener Museums" for 1839 , the full title being "Neue Gattungen von Binnenwürmern, nebst einen Nachtrage zur Monographie der Amphistomen."

As this work is probably little, if at all, known in the countries now necessarily most interested in the history of this entozoon, I cannot, perhaps, do better than transcribe Dr. Diesing's brief notice of the original discovery, together with his description of the external characters presented by the worm. After naming the parasite Stephanutrus, on account of the coronet-like figure of the tail of the male, and giving a technical description of the species, he continues as follows:- "At Barra do Rio Negro, on the 24,th of March, 1834 , Natterer discovered this peculiar genus occurring singly or several together in capsules situated amongst the layers of fat, in a Chinese race of Sus scrofa domestica. Placed in water or in spirits of wine, they stretched themselves considerably, and almost all moved up and down."

"The males measure from ten to thirteen liries in length, the females from filteen to eighteen lines, the former being scarcely a line in breadth at the middle of the body, whilst the latter are almost a line-and-a-half in thickness. The curved body thickens towards the tail, is transversely ringed, and when viewed with a penetrating lens, is seen to be furnished with integumentary pores. The oral aperture opens widely, and is almost circular ; it is supplied with six marginal teeth, two of which, standing opposed to one another, are larger and stronger than the rest. The tail of the male, when evenly spread out, is surrounded by a crown of five lancet-shaped flaps; the combined flaps being connected together from base to 